\title{
Knowledge Management in Composition of Construction Contracts
}

\author{
Eva Trinkūnienè, Vaidotas Trinkūnas
}

\begin{abstract}
A B S T R A C T
Objective: The objective of this paper is to present a model which will allow knowledge management in construction contracts composition.

Research Design \& Methods: It was decided to investigate the possibilities to manage knowledge in constructions contracts composition. The complexity of construction process interested parties, construction contract life cycle, multilayer construction contracts modelling possibilities were evaluated.
\end{abstract}

Findings: There are many possibilities for construction contracts composition. In order to make well-considered construction contract it is not enough to know the civil law, construction, management and so on. You have to use experience earned during long time. Good practice and earlier mistakes have to be evaluated.

Implications \& Recommendations: Proposed model can be used and practically implemented in construction contracts evaluation system. The structure of proposed model allows realising complex view to contract preparation, evaluate corporation knowledge and can be very helpful for construction contractors, subcontractors, investors and other related construction process participants which can improve construction contracting using collected experience and best practice in construction contract making allows to avoid mistakes.

Contribution \& Value Added: In the following research, model of information system for construction contracts structural analysis (previously developed by the authors) is additionally developed by taking into consideration the possibility to use the knowledge management.

\begin{tabular}{|c|c|c|c|c|}
\hline Article type: & research paper & & & \\
\hline Keywords: & $\begin{array}{l}\text { knowledge management; } \\
\text { evaluation }\end{array}$ & construction & contracts; & contracts \\
\hline JEL codes: & K120 & & & \\
\hline Received: & Revised: 15 Oct & ber 2014 & & mber 2014 \\
\hline
\end{tabular}

\section{Suggested citation:}

Trinkuniene, E., \& Trinkunas, V. (2014). Knowledge Management in Composition of Construction Contracts. Entrepreneurial Business and Economics Review, 2(4), 101-112, DOI: http://dx.doi.org/10.15678/EBER.2014.020407. 


\section{INTRODUCTION}

Construction is becoming one of the most important parts of economy. According to the Ministry of Economy of The Republic of Lithuania in the year 2012 share of investments in construction sector was more than $55 \%$ of all country material investments. According to the Statistics Lithuania in the year 2013 the investments growth was $12.3 \%$, comparing to the year 2012. The construction sector is very important not only for Lithuania but also for all Europe Union countries. This sector creates about $10 \%$ of GDP in Lithuania.

The importance of construction sector predicts very large number of participants. According to the international NACE classification the main activities related to the construction sector are construction of buildings, civil engineering, specialised construction activities such as demolition and site preparation, electrical, plumbing and other construction installation activities, building completion and finishing. There are many participants with different tasks and functions also (Figure 1). Those make construction not only one of most important but also one of most complicated processes with a number of stages, which must be appropriately adjusted and managed.

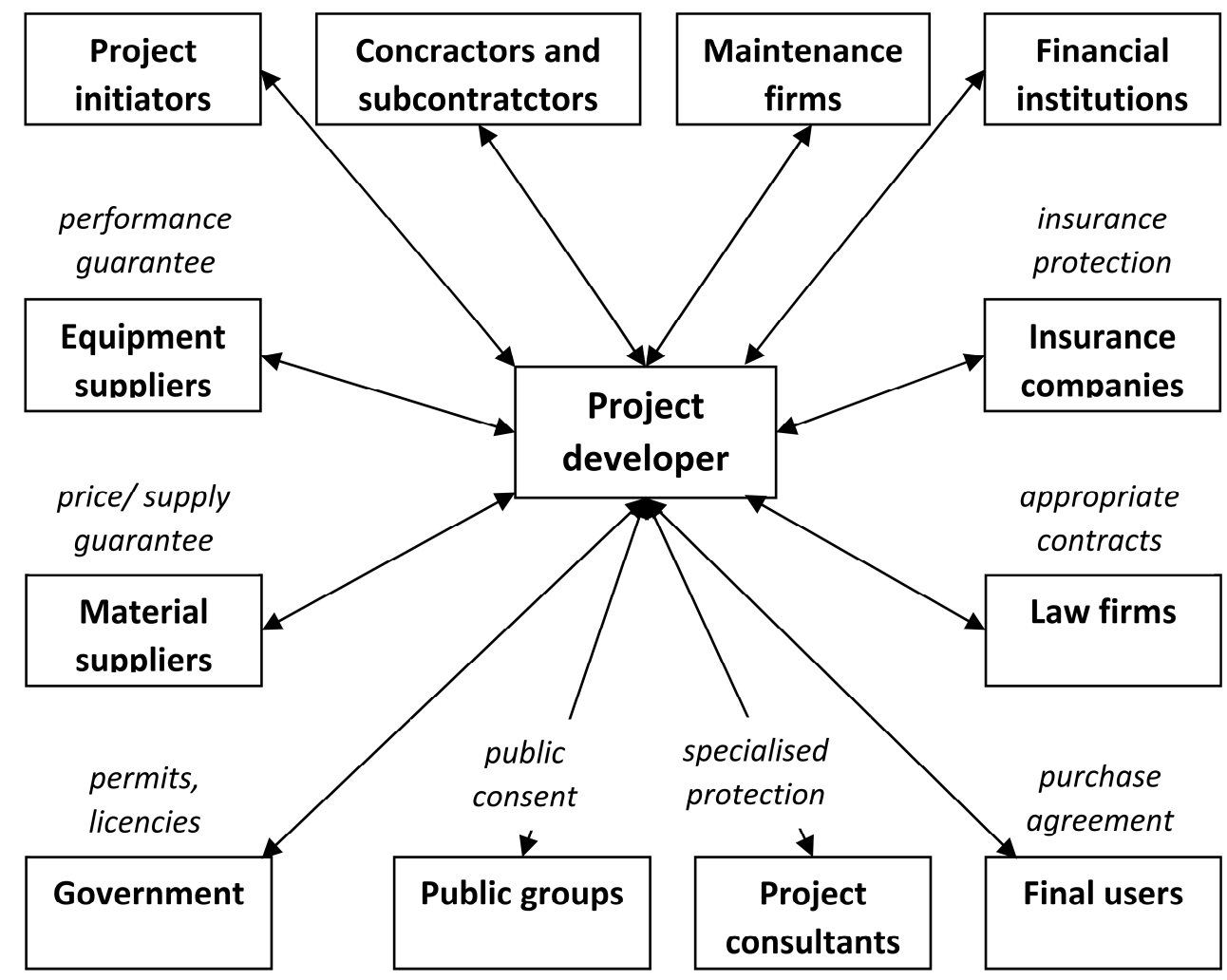

Figure 1. Main interested groups in construction project development Source: own study. 
All the construction process, terms, financing conditions, security requirements, risk management and final results (Mitkus \& Trinkuniene, 2008) must to be considered and clearly described in construction contract. It is important to take into consideration that contracts have to be signed among all different participants and there is not possible to have one typical contract.

There are many numbers of projects taking place around the world and contracts are signed for each project comprising of major firms in action. The client parties shall quote their title objective in the contract and expect the contractor to abide by their agreement for mutual benefits. This shows the importance of contract strategy, requires huge and extensive knowledge and experience. This makes construction contract making difficult process where founds the pale using of specialised information systems. Using specialised information system allows not only collect big amount of related data, implement specialised models for contracts evaluation, but also makes contract making structured, more clear process with the possibility to use collected experience in different fields negotiated under the contract. The objective and is the formation of information systems model for construction contracts structural analysis. The aim of this article is to present the model, which allows making contracts structural analysis and using earned knowledge and best practice in a particular area.

\section{LITERATURE REVIEW}

The analysis of different publication related to the construction contracts making, use of information systems and technology in construction, decision making and structural analysis were performed. In this part some publications related to mentioned areas are briefly reviewed.

Construction process associates with great responsibility, important decisions, effective management, etc. Because of the significance and various risks, complexity and importance the construction sector is under consideration by different authors. More and more challenges are related to information and communication technologies. Different authors describe those research results in this field. The research is related to general usage of information technologies. For example Chen and Kamara (2011) introduced a framework for the implementation of mobile computing on construction sites, which comprised an application model and a technical model. Some research works are more concentrated on different level decisions. Chen, Okudan and Riley (2010) described Construction Method Selection Model (CMSM), which is designed to aid building team members during early project stages in evaluating the feasibility of prefabrication and exploring an optimal strategy to apply prefabrication in concrete buildings. Aguilar and Hewage (2013) described the system that transmits safety related information of multiple construction projects into a centralised database, where realtime safety indicators are generated.

Scientific literature increasingly pays attention to analysis of construction contracts in general, but separate parts and stages of the contract, too. Skitmore analysed construction contracts by various aspects. He alone and with coauthors prepared many different publications on research in this field. During the recent years of this research Xiong, Skitmore, Xia, Masrom, Ye and Bridge (2013) analysed how the performance of construction project participants affects contractor project satisfaction in terms of the 
client's clarity of objectives and promptness of payments, designer carefulness, construction risk management, the effectiveness of their contribution and mutual respect and trust. Skitmore (2008) analysed construction auctions organising theory and practice; Skitmore and Smyth (2007) described pricing of construction works from marketing viewpoint. Skitmore, Pettitt, and McVinish (2007) analysed possibilities to use Gates' method in evaluating closed-bid competitive procurement auctions in order to determine the probability of placing a winning bid for a given mark-up level.

Tieva and Junnone (2009) analysed possibilities of proactive contracting in Finnish public-private partnership projects. They clarify what proactive law is about in terms of contract law and contracting especially in public-private partnership. They discussed the risks in risk management in terms of proactive law while focusing on public-private partnership in Finland.

Dutch housing associations use procurement methods such as performance-based maintenance in order to maintain their housing stock. For contractors a performancebased approach implies major challenges in methods and work processes. Straub and Van Mossel (2007) analysed the execution of activities such as providing advice on maintenance strategies, the design of maintenance scenarios, performance measurements and conducting customer satisfaction surveys in order to contractors selection for performance-based maintenance partnerships.

Even when the construction contractor is selected and the price, work terms and other conditions are negotiated, there is the possibility to choose at least several variants of contracts. Selection of the most favourable variant is a multiple criteria task, and different methodology can be used for its solution.

Important role in every process in construction belongs to consultants. Chow and $\mathrm{Ng}$ (2007) derived that more and more clients seek to measure the performance of Engineering Consultants and amass a set of Consultant Performance Evaluation records with an intention to monitor the quality of consultancy service and facilitate subsequent decisions. In those research set of common Consultant Performance Evaluation criteria pertinent to the service offered at the design stage and the Quantitative Indicators pertinent to each criterion are first identified. In order to improve the fairness of Consultant Performance Evaluation, the expectations that best describe the various performance levels of each Quantitative Indicator are unveiled. Having a better understanding of the expectations of various performance levels could ensure the Consultant Performance Evaluation conducted in a more objective and unified manner.

Multicriteria methods may be used not only for selection of contractors or consultants. Zavadskas, Ustinovičius and Stasiulionis (2004) have analysed possibilities to apply Electre III method evaluating the effectiveness of investment to commercial objects. The authors note that while evaluating effectiveness of investment to commercial objects, total effect of various criteria must also be evaluated: amount of construction works in commercial objects, trends, legal issues and available construction solutions.

Maintenance of existing buildings is also important. It is expedient to make a multicriteria system for decision-making related to buildings' maintenance. Vilutienè and Zavadskas (2003) have presented a system of criteria, which helps to make decisions related to maintenance of residential houses. Evaluation was made using the following 
multicriteria methods: WSM (weighted sum model), WPM (weighted product model), AHP (analytic hierarchy process), ELECTRE and TOPSIS methods' variation and the multicriteria complex proportional evaluation method. A new model was introduced after the research. The model helps to organise management processes in buildings' economy more effectively and to improve work quality.

Possibilities to use various methods of the game theory while making decisions in the construction sector were analysed by Zavadskas, Ustinovičius, Turskis, Peldschus and Messing (2002). Authors have created a software which enables calculations using simple min-max principle, extended min-max principle, Wald's rule, Savage criterion, Hurwicz's rule, Laplace's rule, Bayes's rule and Hodges-Lehmann's rule. Investment to construction or reconstruction of a residential house in $\mathrm{Nida}$ is provided as an example of this software.

Another important issue in construction is selection of construction materials. Zavadskas, Kaklauskas and Trinkūnas $(2002,2003)$ have analysed systems of e-trading for construction materials and goods and offered the model of an internet decision support system for trading in construction materials. The model is based on determining criteria which define construction materials and goods, on importance of the criteria and on application of multicriteria evaluation methods. A pilot internet decision support system for trading in construction materials was created on the basis of the model suggested by the authors.

Multiple criteria methods can vary depending on different criteria. Different authors described usability of different multiple criteria methods: MOORA method (Braurs et al. 2008; Braurs \& Zavadskas, 2009), SAW and CLARA methods (Shevchenko et al., 2008), Game theory methods (Peldschus, 2008), AHP approach (Podvezko, 2009). Some of authors (Turskis, 2008; Ustinovichius et al., 2009; Ginevicius et al., 2008) analysed the use possibilities of different multiple criteria methods for different purposes.

Observations and literature analysis according to the construction contracts making, use of information systems and technology in construction, decision making and structural analysis show that different techniques and methods can be applied but there is still the question how those useful researches connect into one system which makes the possibility for construction contracts structural analysis.

Authors presented model of information system for construction contracts structural analysis (Trinkuniene \& Trinkunas, 2014). In the following research, this model was additionally developed by taking into consideration the possibility to use the knowledge management.

\section{MATERIAL AND METHODS}

The basis of developed multilayer contracts modeling system is made on construction contract life cycle model (Figure 2).

Each of the construction contract lifecycle phases have its input and output information. And each phase has its own purpose:

- Contract request phase - different parties of the construction process can use such system and there are different types of the contracts. In this phase user is at the starting point and have to decide which type of the contract he/she needs. 
- Authoring phase - there are a lot of different contracts, but in most cases it is impossible to use exactly the same contract few times. At this point user can edit existing contracts so it matches existing needs.

- Negotiation phase - this phase is related to the presentation of drafts and versions of authorised contracts for review by other employees, or even vendors/customers/clients, etc.

- Approvals phase - in most cases construction contracts are complex and have to be checked by different stakeholders, even within the same organisation. Such reviewers can be: authorised staff, different subject matter experts, legal and appropriate.

- Contract execution phase - at this phase final contract has to be prepared and signed.

- Obligations phase - the life of a contract and its relationships continues and does not end after signing the contract. At this moment starts very important post-execution stage with alerts, workflow processes, risk assessment, spend management, compliance monitoring, and advanced reporting metrics.

- Compliance phase - reporting capabilities provide organisations with visibility into all contractual relationships including fully audit for contract.

- Contract renewal phase - this phase is related to the organizations' possibility to capitalise on each and every renewal opportunity by identifying candidates for renewal, alerting employees to these contracts in time to make business decisions, and creating new contracts or drafts based on existing ones.

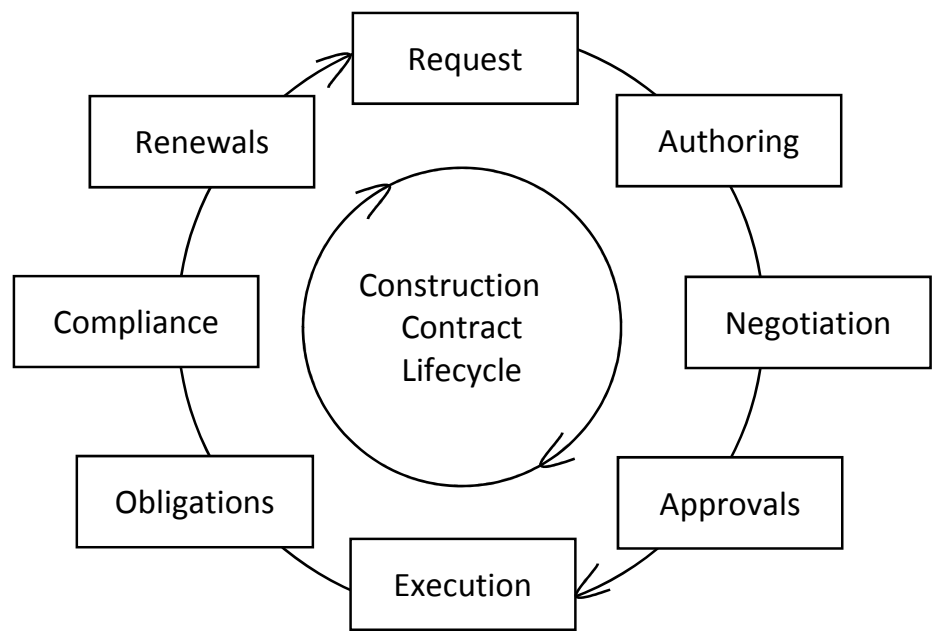

Figure 2. Construction contract life cycle model Source: own study.

Each phase consists of different elements which are very important in the realisation of the purpose related to the exact phase. There are different structures for each phase, and those have to be analysed separately.

At the same time if we talk about contract request or renewal phases we can see stronger or not so strong relations among different contracts. This makes the possibility to use an existing experience and organise all information system as multilayer contracts modeling system. 


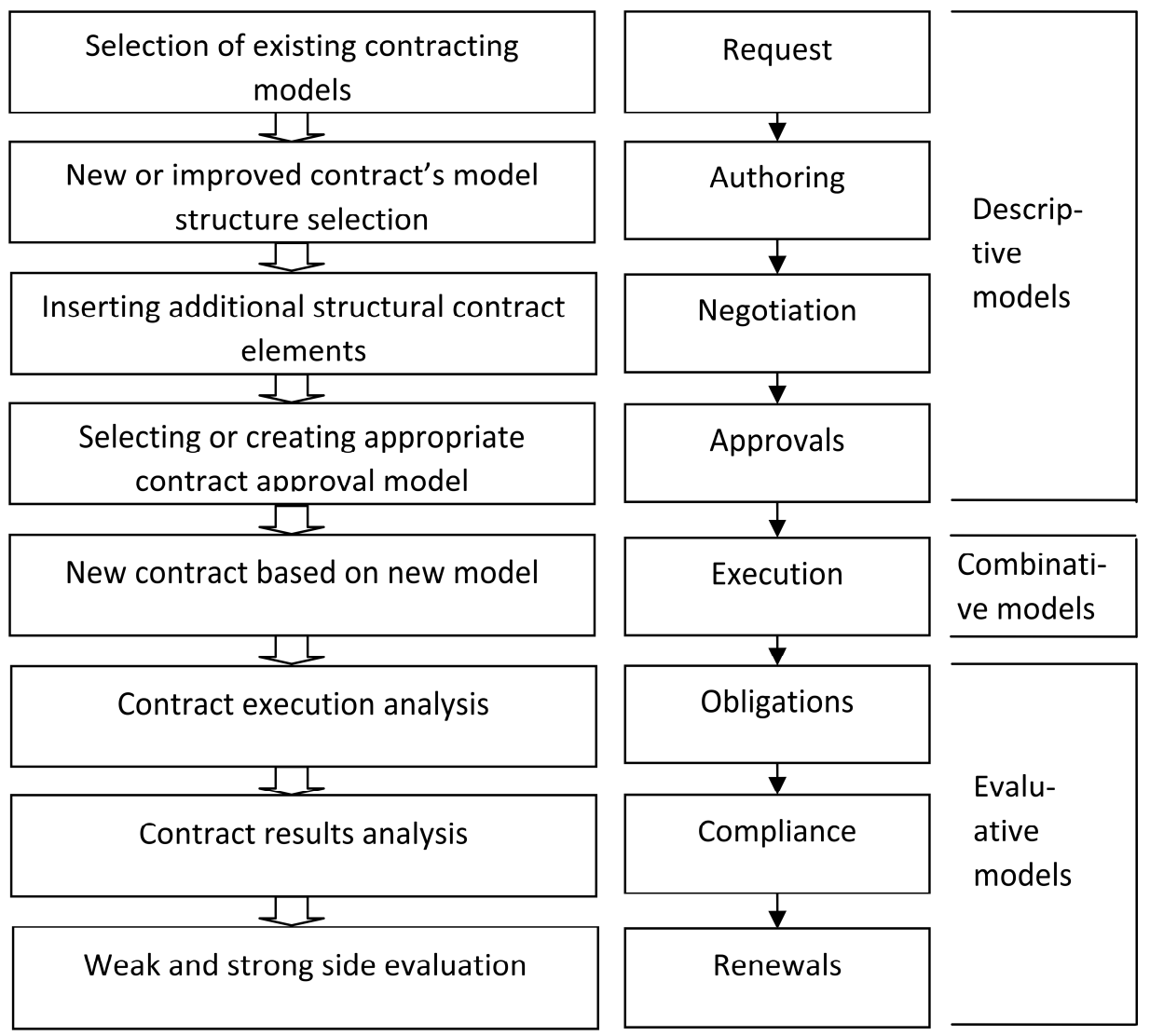

Figure 3. Multilayer construction contracts modeling systems structure Source: own study.

Throughout construction contract making process numerous models are needed, which are often created independently and designed to solve different tasks.

In order to make construction contract there is no one right model. There are different models with different strong and weak sides. Taking this principle into account multilayer construction contracts modeling system architecture was created and presented in Figure 3.

The basis for this model is taken from construction contract lifecycle model (Figure 2 ). One phase of construction contracts life cycle constrains one layer in construction contracts modelling system structure. There are 8 separate layers. Each layer consists of its own schemas and discovered gaps in those schemas are filled by creating new schemas. The main idea is that number of schemas is not limited and each new schema helps to solve different tasks and makes possibility to improve contracts in the future. According to these principle models are grouped in three classes: descriptive models, combinative models and evaluation models (Figure 2).

Descriptive models class consists of four levels. Those levels are organised in hierarchical manner. All those levels are described in construction contract lifecycle model description. 
The class of combinative models contains only one element or one layer. It means that upper four layers are linked together via process model.

Evaluative models class is constructed from three levels which represents evaluation in different stages of construction contracts implementation. With the process-centric integration of engineering, management, legal and other information and properly organised ontology it is possible to create a variety of new formalised evaluative models which helps to use semi-automatic or automatic analysis of created structures.

During assessment or interpretation of evaluation results, different construction contract provisions may be treated differently. This, on its turn, may cause some misunderstanding, erroneous results or erroneous interpretation of the results. Therefore, it is very important to elaborate each construction contract provision.

As the possible authoring layer structure it was used scheme were expert evaluation methods was adapted. In order to determine indicator significance in calculations more objectively, an opinion of a group of experts was evaluated.

The experts were surveyed by questionnaires. The questionnaire was prepared on the basis of the method of paired evaluation of indicator significance. The generalised calculations of survey results showed that the compatibility of expert opinions meets the requirements; therefore, it is possible to claim that indicator significances derived during the expert survey are reliable and can be used for typical evaluation of contract. However, these indicator significances would change with changing economic situation and upon evaluation of specific requirements of a construction project; anyway they serve as a basis for initial calculations.

It is good solution to use experts, but it is not always the best way. For example it is necessary to make the contract during short time, or experts can be busy at those main positions and it makes problems to organise evaluation process, the experts can change and new experts do not have enough experience. It looks that proposed model have to be improved by evaluating the knowledge gained during company life. It means that the model has included knowledge management possibility.

\section{RESULTS AND DISCUSSION}

Knowledge management decisions make possible getting the right knowledge to the right person at the right time. This may not seem so complex itself, but it implies a strong tie to corporate strategy, understanding of where and in what forms knowledge exists, creating processes that span organisational functions, and ensuring that initiatives are accepted and supported by organisational members. In our case, most important is possibility to use knowledge management in new knowledge creation, knowledge sharing, storage, and refinement.

The objective of knowledge management solution is to create value and to leverage, improve, and refine the firm's competences and knowledge assets to meet organisational goals and targets which are directly implemented in contracts. Implementing knowledge management has to be based on few separate organisational levels: 
- Strategic - it necessary to manage, share, and create relevant knowledge assets that will help meet tactical and strategic corporate requirements.

- Corporate culture - the way people interact inside of the organisation, how the knowledge is created, how the changes are made, and how the knowledge is shared.

- Implementational - processes, environments, and systems that enable implementation of knowledge management in the organisation.

- Technological - properly designed and implemented systems, tools, and technologies.

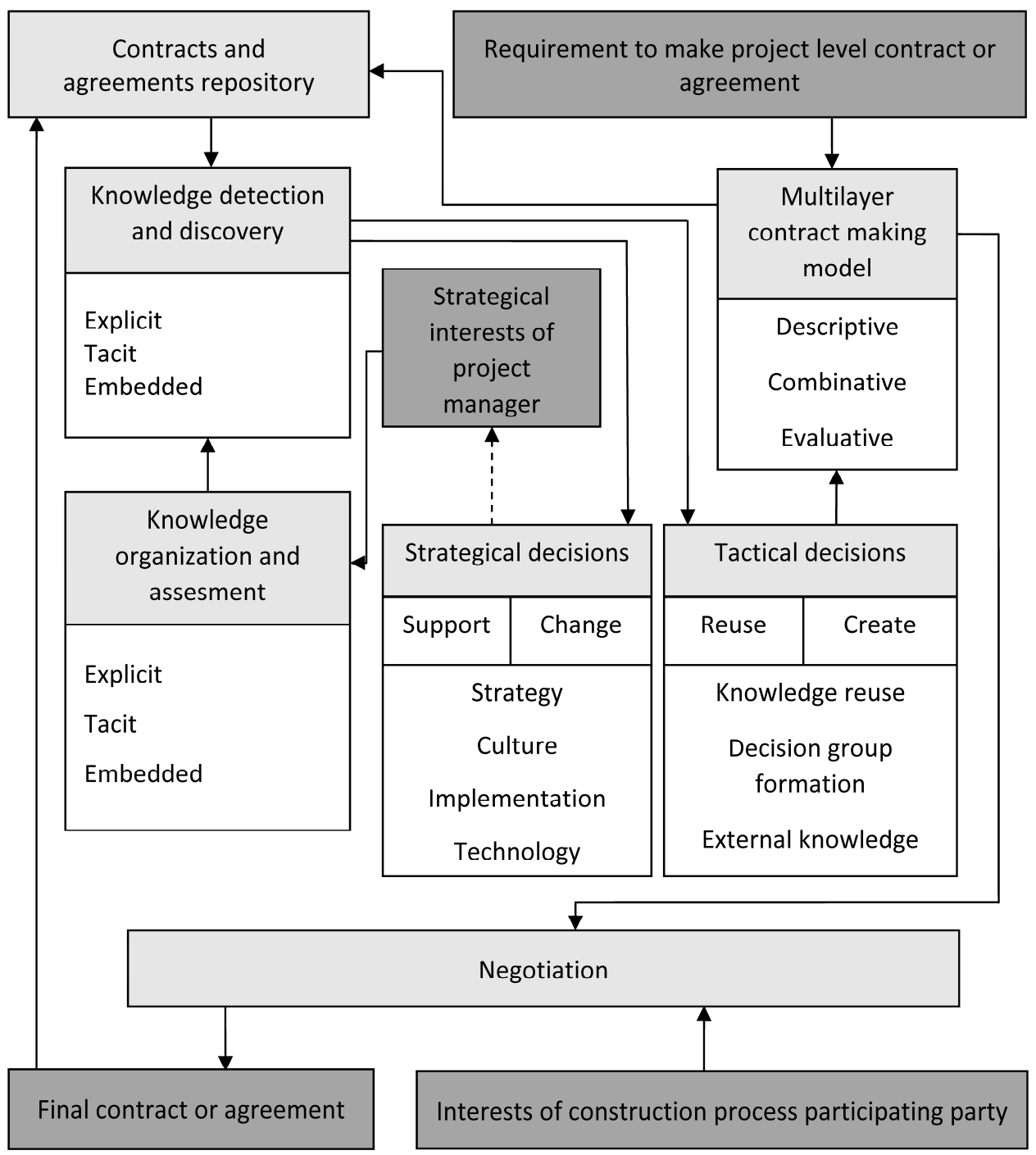

Figure 4. Knowledge management model for construction contracts information system Source: own study. 
Proposed model of knowledge management in forming construction contracts is presented in figure 4. Model consists of such basic elements:

- Contracts and agreements repository - includes all contracts and related records like tacit and embedded knowledge taken into consideration responsible people, organisational culture, and processes.

- Module for knowledge detection and discovery - identifying existing knowledge sources, discovering hidden knowledge in data and information. This module consists of three knowledge groups: explicit knowledge (documents, different data sources etc.); tacit knowledge (surveys, questionnaires, interviews etc.); embedded knowledge (reverse engineering, knowledge retrieved from procedures, products etc. with help of special identifying tools).

- Module for strategic decisions - allows making strategic decisions at different organisational levels. It can be decision to support existing model or improve it by making changes.

- Module for tactical decisions - supposes to make possible tactical decisions in contract forming process. It can be some possible solutions such as reusing existing knowledge, improving basic models, forming special decision group, getting additional information from external sources (external data bases, customers, competitors, partners etc.).

- Multilayer contract making model - makes the structural basis for construction contract making at free different layers (descriptive, comparative and evaluative).

Proposed model presents basic structure of knowledge management model and can be implemented only by taking into consideration exact possibilities to adopt it to a particular company. Mode is important from practical point of view as it makes suggestions to improve construction contracts making process and contracts quality.

\section{CONCLUSIONS}

Proposed model of specialised information system for construction contracts preparation allows not only collecting big amount of related data, implementing specialised models for contracts evaluation, but also made contract making structured, clearer process with possibility to use collected experience in different fields negotiated under the contract. Therefore information systems model for construction contracts structural analysis was prepared. This model is based on construction contract lifecycle and multilayer structure and additionally extended with knowledge management model. The structure of proposed model allows realising complex view to contract preparation, evaluate corporation knowledge and can be very helpful for construction contractors, subcontractors, investors and other related construction process participants which can improve construction contracting using collected experience.

Knowledge management decisions make possible getting the right knowledge to the right person at the right time. This in itself may not seem so complex, but it implies a strong tie to corporate strategy, understanding of where and in what forms knowledge exists, creating processes that span organisational functions, and ensuring that initiatives are accepted and supported by organisational members. 


\section{REFERENCES}

Adriaanse, J. (2007). Construction contract law. New York: Palgrave Macmillan.

Aguilar, G.E., \& Hewage, K.N. (2013). IT based system for construction safety management and monitoring: C-RTICS, Automation in Construction, 35, 217-228.

Brauers, W.K.M., Zavadskas, E.K., Turskis, Z., \& Vilutiene, T. (2008). Multi-objective contractor's ranking by applying the Moora method. Journal of Business Economics and Management, 9(4), 245-255.

Brauers, W.K., \& Zavadskas, E.K. (2009). Robustness of the multi-objective moora method with a test for the facilities sector. Technological and Economic Development of Economy, 15(2), 352-375.

Chen, Y., Okudan, G.E., \& Riley, D.R. (2010). Decision support for construction method selection in concrete buildings: Prefabrication adoption and optimisation, Automation in Construction, 19, 665-675.

Chen, Y., \& Kamara, J.M. (2011). A framework for using mobile computing for information management on construction sites. Automation in Construction, 20, 776-788.

Chow, L.K., \& Ng, S.T. (2007). Expectation of performance levels pertinent to consultant performance evaluation. International Journal of Project Management, 25(1), 90-103.

Ginevicius, R., Podvezko, V., \& Raslanas, S. (2008). Evaluating the Alternative Solutions of Wall Insulation by Multicriteria Methods. Journal of Civil Engineering and Management, 14(4), 217-226.

Mitkus, S. \& Trinkuniene, E. (2008). Reasoned Decisions in Construction Contracts Evaluation. Journal of Technological and Economic Development of Economy, 14(3), 402-415.

Peldschus, F. (2008). Experience of the Game Theory Application in Construction Management. Journal of Technological and Economic Development of Economy, 14(4), 531-545.

Podvezko, V. (2009). Application of AHP technique. Journal of Business Economics and Management, 10(2), 181-189.

Shevchenko, G., Ustinovichius, L., \& Andruskevicius, A. (2008). Multi-attribute Analysis of Investments Risk Alternatives in Construction. Journal of Technological and Economic Development of Economy, 14(3), 428-443.

Skitmore, R.M., \& Smyth, H. (2007). Pricing construction work: a marketing viewpoint. Construction Management and Economics, 25(6), 619-30.

Skitmore, M., Pettitt, A.N., \& McVinish, R.S. (2007). Gates' bidding model. Journal of Construction Engineering and Management, 133(11). 855-863.

Skitmore, R.M. (2008). First and second price independent values sealed bid procurement auctions: some scalar equilibrium results. Construction Management and Economics, 26(8), 785-801.

Straub, A., \& van Mossel, H.J. (2007). Contractor Selection for Performance-Based Maintenance Partnerships. International Journal of Strategic Property Management, (11), 65-76.

Tieva, A., \& Junnone, J.M. (2009). Proactive Contracting in Finnish PPP Projects. International Journal of Strategic Property Management, (13), 219-228.

Trinkūnas, V., Kaklauskas, A., \& Zavadskas, E.K. (2002). Selection of Rational Construction Products Regarding Building Refurbichments. Property Management, 6(2), 74-82.

Trinkūnas, V., Kaklauskas, A., \& Zavadskas, E.K. (2003). The Use of Computer Technologies in Sales of Construction Products. Journal of Civil Engineering and Management, 9(1), 25-31. 
Turskis, Z. (2008). Multi-Attribute Contractors Ranking Method by Applying Ordering Feasible Alternatives of Solutions in Terms of Preferability Technique. Journal of Technological and Economical Development, 14( 2) , 224-239.

Ustinovichius, L., Barvidas, A., Vishnevskaja, A., \& Ashikhmin, I.V. (2009). Multicriteria Verbal Analysis for the Decision of Construction Problems. Journal of Technological and Economic Development of Economy, 15( 2) , 326-340.

Vilutienè, T., \& Zavadskas, E. K. (2003). The Application of Multi-criteria Analysis to Decision Support for the Facility Management of a Residential District. Journal of Civil Engineering and Management, 11(4), 241-252.

Xiong, B., Skitmore, M., Xia, B., Masrom, M.A., Ye, K., \& Bridge, A. (2014). Examining the influence of participant performance factors on contractor satisfaction: A structural equation model. International Journal of Project Management, 32(3), 482-491.

Zavadskas, E.K., Ustinovičius, L., \& Stasiulionis, A. (2004). Multicriteria Valuation of Commercial Construction Projects for Investment Purposes. Journal of Civil Engineering and Management, 10(2), 151-166.

Zavadskas, E.K., Ustinovičius, L., Turskis, Z., Peldschus, F., \& Messing, D. (2002). LEVI 3.0 - Multiple Criteria Evaluation Program for Construction Solutions. Journal of Civil Engineering and Management, 8(3), 184-191.

\section{Authors}

Contribution share of authors is equal and amounted to $50 \%$ for each of them.

\section{Eva Trinkūnienè}

Bachelor of Business Administration (Vilnius Gediminas Technical University, Lithuania); Master in Law sciences (University of Law, Lithuania); Master in Business Management (Vilnius Gediminas Technical University, Lithuania); Doctor in technological sciences (Vilnius Gediminas Technical University, Lithuania).

\section{Vaidotas Trinkūnas}

Bachelor of Business Administration (Vilnius Gediminas Technical University, Lithuania); Master in Law sciences (University of Law, Lithuania); Master in Business Management (Vilnius Gediminas Technical University, Lithuania); Doctor in technological sciences (Vilnius Gediminas Technical University, Lithuania)

\section{Correspondence to:}

Assoc. Prof. Eva Trinkūnienè

Vilnius Gediminas Technical University

Faculty of Business Management,

Sauletekio al. 11, 10223 Vilnius, Lithuania

eva.trinkuniene@vgtu.It

\section{Copyright and License}

This article is published under the terms of the Creative Commons Attribution - NonCommercial - NoDerivs (CC BY-NC-ND 3.0) License

http://creativecommons.org/licenses/by-nc-nd/3.0/ 